\title{
The Right to Venue and the Right to an Impartial Jury: Resolving the Conflict in the Federal Constitution
}

The sixth amendment to the United States Constitution requires that federal criminal defendants be tried by "an impartial jury of the State and district wherein the crime shall have been committed." In an ordinary criminal case, courts are able to accommodate both the defendant's right to venue ${ }^{2}$ and his right to an impartial jury by using such remedial measures as voir dire and continuances. ${ }^{3}$ If there has been extensive pretrial publicity, however, the risk of prejudice to the defendant in the district where the crime was committed may be so great that these remedies are inadequate to protect his right to an impartial jury. ${ }^{4}$ The Supreme

U.S. Const. amend. VI.

2 Technically, the sixth amendment is a vicinage provision because it defines the geographical area from which the jury must be selected, while article III, section 2, clause 3 of the Constitution, which guarantees a criminal defendant's right to trial "in the State where the said Crimes shall have been committed," is a venue provision because it fixes the place of trial. See 2 Charles Wright, Federal Practice and Procedure § 301, at 190 (2d ed. 1982). The Supreme Court, however, has held that the sixth amendment guarantees a federal criminal defendant's right to trial in the district where the crime was committed as well as his right to a jury selected from that district. See, e.g., Johnston v. United States, 351 U.S. 215, 220 (1956); Salinger v. Loisel, 265 U.S. 224, 232-33 (1924). This accords with the framers' intention that the sixth amendment create a right to venue as well as a right to vicinage. See Francis Heller, The Sixth Amendment to the Constitution of the United STATEs 93 (1951) ("II]f the debates in the state conventions can be taken as typical, those who clamored for more specific and narrowly defined criteria of vicinage were frequently speaking in terms of venue, or at least they failed to distinguish clearly between vicinage and venue, between origin of the jury and location of the trial."). But see Kershen, Vicinage (pt. 1), 29 OKLA. L. Rev. 801, 804 (1976) (arguing that the merger of these two concepts is not an "accurate statement of the importance attached to the distinction between venue and vicinage by the drafters" of the art. III provision and the sixth amendment). This comment will refer to the sixth amendment as establishing a right to venue in the district where the crime was committed.

s See, e.g., Nebraska Press Ass'n v. Stuart, 427 U.S. 539, 551 (1976) ("In the overwhelming majority of criminal trials, pretrial publicity presents few unmanageable threats to [the right to an impartial jury]."); Wright, Fair Trial-Free Press, 38 F.R.D. 435, 435-38 (1965) (in most criminal cases, existing safeguards are sufficient to ensure that the defendant's right to an impartial jury is not violated).

See, e.g., Groppi v. Wisconsin, 400 U.S. 505, 509-10 (1971) (remedies such as voir dire and continuances may be inadequate "where, because of prejudicial publicity or for some other reason, the community ... may already be permeated with hostility toward the defendant"); infra notes $12-21$ and accompanying text. 
Court has held that in such a situation the defendant is constitutionally entitled to a change of venue whenever such a change is necessary to ensure an impartial jury. ${ }^{5} \mathrm{~A}$ federal defendant confronted with the risk of a partial jury usually waives his right to venue by moving under Rule 21(a) of the Federal Rules of Criminal Procedure for a change of venue, ${ }^{6}$ but if he insists on both his right to venue and his right to an impartial jury, these two rights come into conflict.

This comment examines the problem that arises when a fed$\mathrm{eral}^{7}$ criminal defendant refuses to waive his right to venue in a

B See Groppi v. Wisconsin, 400 U.S. 505, 510-11 (1971) (holding that in some cases, "only a change of venue [is] constitutionally sufficient to assure . . . [an] impartial jury"); Rideau v. Louisiana, 373 U.S. 723, 726-27 (1963) (discussed infra notes 23-26 and accompanying text). Although both Rideau and Groppi in fact addressed the problem of when the fourteenth amendment requires a state court to allow a change of venue, see Groppi, 400 U.S. at 510; Rideau, 373 U.S. at 726-27, the standards are the same for federal trials under the sixth amendment, see, e.g., Nebraska Press Ass'n v. Stuart, 427 U.S. 539, 551 (1976); United States v. Faul, 748 F.2d 1204, 1216 n.9 (8th Cir. 1984).

${ }^{6}$ FED. R. CrIm. P. 21(a) provides in relevant part that "[t]he court upon motion of the defendant shall transfer the proceeding as to him to another district .... if the court is satisfied that there exists in the district where the prosecution is pending so great a prejudice against the defendant that he cannot obtain a fair and impartial trial." By making a motion under Rule 21(a) for a change of venue, a defendant waives his right to venue. See FED. R. CRIM. P. 21(a) advisory committee note; see also United States v. Roberts, 618 F.2d 530, 537 (9th Cir. 1980) (constitutional right to venue is waivable).

' State courts have also considered what remedy is appropriate when a defendant refuses to waive his right to venue under a state constitution even though a change of venue is necessary to assure an impartial jury. See, e.g., State v. Thompson, 273 Minn. 1, 34-36, 139 N.W.2d 490, 513-15 (1966) (rejecting defendant's motion for a new trial even though over $60 \%$ of the prospective jurors expressed an opinion that the accused was guilty); Commonwealth v. Douglas, $461 \mathrm{~Pa} .749,753,337$ A.2d 860, 862 (1975) (denying defendant's motion for dismissal because "no jurisdiction . . . has ever advocated quashing the indictment as a remedy" for prejudicial pretrial publicity); State v. Holland, 261 S.C. 488, 494-95, 201 S.E.2d 118, 121-22 (1973) (rejecting the defendant's motion to dismiss because there was no motion for a change of venue); State ex rel. Schulter v. Roraff, 39 Wis. 2d 342, 352, 159 N.W.2d 25, 30-31 (1968) (holding that a defendant "cannot insist on a jury trial in the county wherein the offense was committed and also claim the county is prejudiced"), cert. denied, 393 U.S. 1066 (1969); State v. Woodington, 31 Wis. 2d 151, 167-68, 142 N.W.2d 810, 818 (1966) (concluding that dismissal was unjustified because defendant had moved neither for a continuance nor for a change of venue), appeal dismissed and cert. denied, 386 U.S. 9 (1967).

The Supreme Court has incorporated the sixth amendment guarantee of an impartial jury into the due process clause of the fourteenth amendment, see cases cited infra note 11, but courts have generally not applied the sixth amendment right to venue to state criminal proceedings, see, e.g., Zicarelli v. Dietz, 633 F.2d 312, 325-26 (3d Cir. 1980), cert. denied, 449 U.S. 1083 (1981); State v. Byrnes, 260 Iowa 765, 768-69, 150 N.W.2d 280, 281-82 (1967); People v. Lee, 334 Mich. 217, 224-25, 54 N.W.2d 305, 308 (1952); but see People v. Jones, 9 Cal. 3d 546, 551, 510 P.2d 705, 709, 108 Cal. Rptr. 345, 349 (1973) (holding that sixth amendment venue provision is applicable to the states). The refusal to incorporate the sixth amendment venue provision is not surprising, since the framers intended this provision to apply to the federal judicial districts established by Congress. See, e.g., Zicarelli, 633 F.2d at 
case in which a change of venue is the only remedy that will protect his right to an impartial jury. At least one federal court has held that, in this situation, the only proper remedy is to dismiss the case. ${ }^{8}$ Most federal courts, however, have responded by, in effect, presuming that the jury in the district where the crime was committed is impartial if the defendant refuses to move for a change of venue. ${ }^{9}$ This comment offers an alternative resolution of the conflict between the right to an impartial jury and the right to venue, one that is suggested by the history and purposes of the sixth amendment: in cases in which the defendant cannot be tried by an impartial jury of the district yet refuses to move for a change of venue, the court should order a change of venue to another district.

Part I of this comment discusses the circumstances in which a conflict may develop between a federal criminal defendant's right to venue and his right to an impartial jury and then criticizes the two ways in which courts have addressed this problem-dismissal of the case and the presumption of impartiality in the venue. Both of these approaches resolve the problem by assuming that the right to venue is an absolute right that only the defendant can waive. Part II examines the purposes underlying the sixth amendment right to venue and argues that the framers did not intend a criminal defendant's right to venue to be so strictly construed; rather, they intended that this right be conditioned on the government's ability to try the defendant. In order to resolve this conflict, the comment therefore proposes that in cases where a change of venue is required to protect a defendant's right to an impartial jury but the defendant refuses to move for a change of venue, the court should order a change of venue to another district.

\section{The Conflict Between a CRiminal Defendant's Right to an Impartial JuRy and His Right to Venue}

\section{A. The Problem}

The sixth amendment guarantees a federal criminal defendant both the right to be tried by an impartial jury and the right to a trial in the district where the crime was committed. ${ }^{10}$ Although the

325; Note, Change of Venue in Criminal Cases: The Defendant's Right to Specify the County of Transfer, 26 STAN. L. REv. 131, 149 n.98 (1973). The scope of this comment will be limited to this problem as it arises in federal courts.

- See infra notes 32-36 and accompanying text.

- See infra notes 42-50 and accompanying text.

10 U.S. ConST. amend. VI (quoted in relevant part supra text accompanying note 1). 
degree of partiality necessary to violate the right to an impartial jury cannot be defined with precision, the Supreme Court has held that, at a minimum, this right requires a trial by "a panel of impartial, 'indifferent,' jurors" who will base their verdict solely upon the evidence presented at trial. ${ }^{11}$ Courts have used various devices, principally voir dire and continuances, to ensure that juries impanelled in the district where the crime was committed are impartial. ${ }^{12}$ The questioning of prospective jurors during voir dire is intended to detect jurors who are biased against the defendant. ${ }^{13} \mathrm{~A}$ continuance is also designed to aid in the selection of an impartial jury-a delay in the trial may allow community prejudice against the defendant to dissipate. ${ }^{14}$

Although these remedies function well in ordinary criminal cases, ${ }^{15}$ they may fail to protect a defendant's right to an impartial jury in cases where there has been pervasive adverse pretrial publicity. ${ }^{16}$ In such cases, voir dire may be ineffective in detecting biased jurors either because of a potential juror's reluctance to admit prejudice in court ${ }^{17}$ or because of the difficulty of detecting unconscious bias. ${ }^{18}$ The grant of a continuance may also be insufficient to

11 Irvin v. Dowd, 366 U.S. 717, 721-23 (1961) (applying implicit fourteenth amendment guarantee of an impartial jury); accord Murphy v. Florida, 421 U.S. 794, 799-800 (1975).

${ }_{12}$ See, e.g., Standards Relating to Fair Trial and Fair Press 120, 131 (Tent. Draft 1966) [hereinafter cited as FaIr Trial Standards]; Sullivan, Prejudicial Publicity: A Look at the Remedies, 1 Sufrolk U.L. Rev. 77, 90-92 (1967).

In addition to continuances and voir dire, remedial measures include jury sequestration, change of venue, severance of trials in which defendants are joined, closure, and restraining orders restricting press coverage ("gag orders"). See generally FaIR Trial STANDARDS, supra, at 68-78; Ranney, Remedies for Prejudicial Publicity: A Brief Review, 21 VILL. L. Rev. 819, 822-36 (1976).

${ }^{13}$ See, e.g., United States v. Vera, 701 F.2d 1349, 1355 (11th Cir. 1983) ("The purpose of voir dire is to enable the defendant to evaluate the prospective jurors and select a fair and impartial jury."); cf. Stephen Saltzburg, American Criminal Procedure 878 (2d ed. 1984) (purpose of voir dire "is to get a panel that is free of bias").

${ }^{14}$ See, e.g., Nebraska Press Ass'n v. Stuart, 427 U.S. 539, 563-64 (1976) (continuance "allow[s] public attention to subside"); Groppi v. Wisconsin, 400 U.S. 505, 510 (1971) (grant of continuance may allow "the fires of prejudice" to cool).

${ }_{15}$ See supra notes $2-3$ and accompanying text.

${ }^{16}$ See supra note 4 and accompanying text.

${ }^{17}$ See, e.g., Dennis v. United States, 339 U.S. 162, 176 (1950) (Black, J., dissenting); Fair Trial Standards, supra note 12, at 56-58; Broeder, Voir Dire Examinations: An Empirical Study, 38 S. CAL. L. REv. 503, 528 (1965); Sullivan, supra note 12, at 91-92, 95; Note, Government Consent to Waiver of Jury Trial Under Rule 23(a) of the Federal Rules of Criminal Procedure, 65 YaLE L.J. 1032, 1037 (1956).

${ }_{18}$ See, e.g., Irvin v. Dowd, 366 U.S. 717, 727-28 (1961); United States v. Dennis, 183 F.2d 201, 227 (2d Cir. 1950) (Hand, J.), aff'd, 341 U.S. 494 (1951); Fair Trial Standards, supra note 12, at 61-64; Stanga, Judicial Protection of the Criminal Defendant Against Adverse Press Coverage, 13 WM. \& Mary L. Rev. 1, 2 (1971); Comment, Fair Trial v. Free Press: The Psychological Effect of Pre-Trial Publicity on the Juror's Ability to be Impar- 
ensure that the defendant is tried by an impartial jury. If the continuance is granted only for a short period of time, it is unlikely to eliminate community prejudice against the defendant; ${ }^{19}$ if it is granited for an extended period of time, the defendant's sixth amendment right to a speedy $\operatorname{trial}^{20}$ may be violated before the prejudice disappears. ${ }^{21}$

In cases where these remedies are inadequate to prevent the selection of a partial jury, the Supreme Court has held that a defendant has a constitutional right to move for a change of venue to protect his right to an impartial jury. ${ }^{22}$ In Rideau v. Louisiana, ${ }^{23}$ for example, a film of the defendant's confession to a bank robbery and the murder of one of the hostages was televised three times (to audiences of $24,000,53,000$, and 29,000 ) shortly after the crime was committed. Because there were only 150,000 residents in the county where the crime was committed, the defendant moved for a change of venue to another county within the state in order to ensure that he was tried by an impartial jury, but the state courts rejected his motion. ${ }^{24}$ The Supreme Court reversed the state courts' decision, holding that due process required a change of venue in these circumstances. ${ }^{25}$ The Court reasoned that where the residents of the venue "had been exposed repeatedly and in depth

tial; A Plea for Reform, 38 S. CAL. L. REv. 672, 684 (1965).

10 See, e.g., Groppi v. Wisconsin, 400 U.S. 505, 510 (1971) (grant of continuance may not diminish the prejudice against the defendant); Goldfarb, Public Information, Criminal Trials and the Cause Celebre, 36 N.Y.U. L. REv. 810, 821 (1961) (concluding that "delay may not cause public feelings about a case to subside" and that "[e]ven if delay will cool public sentiment, the press can fan the fires again when the delayed cause finally comes to trial").

20 U.S. Const. amend. VI ("In all criminal prosecutions, the accused shall enjoy the right to a speedy . . . trial . ....").

${ }^{21}$ See, e.g., Groppi v. Wisconsin, 400 U.S. 505, 510 (1971) ("[C]ontinuances, particularly if they are repeated, work against the important values implicit in the constitutional guarantee of a speedy trial.") (footnote omitted); United States v. Abbott Laboratories, 505 F.2d 565, 573 (4th Cir. 1974) ("[T]here are decided limitations on [the use of a continuance] stemming from a defendant's sixth amendment right to a speedy trial."), cert. denied, 420 U.S. 990 (1975).

${ }^{22}$ See supra note 5 and accompanying text. Courts have considered a change of venue in two situations: (1) where continuances and voir dire have been shown to be unsuccessful in selecting an impartial jury, see United States v. Cotton, No. 68-CR-113 (E.D. Wis. June 11, 1969), appeal dismissed, 397 U.S. 45 (1970), reprinted in part in Transcript Dismissing Federal Indictment-Milwaukee 14, 28 Gumb Prac. 101, 102 (1970) [hereinafter cited as Transcript], or (2) where pretrial publicity has been so pervasive and prejudicial that these remedies are found to be per se inadequate to assure an impartial jury, see Rideau v. Louisiana, 373 U.S. $723,726-27$ (1963).

23373 U.S. 723 (1963).

24 Id. at 724-25.

${ }^{25}$ Id. at 726-27. 
to the spectacle of Rideau personally confessing in detail to the crimes with which he was later to be charged. . . . [a]ny subsequent court proceedings [in the venue] could be but a hollow formality." 26

Defendants faced with a partial jury in the district in which the crime was committed will usually waive their right to venue by moving under Rule 21(a) of the Federal Rules of Criminal Procedure for a change of venue. ${ }^{27} \mathrm{~A}$ defendant may, however, stand on his right to venue and insist on the selection of an impartial jury from the district in which the crime was committed; if he does, his right to an impartial jury (which can only be protected by a change of venue in this situation) will conflict with his right to venue. Lower federal courts have refused to order a change of venue when the defendant does not request one, on the theory that the right to venue is an absolute right of the defendant that only he can waive. ${ }^{28}$ These courts have offered two justifications for this conclusion. First, some courts have reasoned that since the sixth amendment right to venue is intended to protect the accused against inconvenience and prejudice, only the defendant should be able to waive this right. ${ }^{29}$ Other courts have relied on Rules 18 and 21(a) of the Federal Rules of Criminal Procedure, which provide that the trial shall take place in the district where the crime was committed unless the defendant moves for a change of venue..$^{30}$

${ }^{26}$ Id. at 726.

${ }^{27}$ FED. R. CRIM. P. 21(a) (quoted in relevant part supra note 6).

${ }^{28}$ See, e.g., United States v. DiJames, 731 F.2d 758, 761 (11th Cir. 1984); United States v. Abbott Laboratories, 505 F.2d 565, 572 (4th Cir. 1974), cert. denied, 420 U.S. 990 (1975); Delaney v. United States, 199 F.2d 107, 116 (1st Cir. 1952); see also 2 C. WRIGHT, supra note 2 , $\S 341$, at 245 (because of constitutional limitations on venue, federal government "cannot move for transfer nor can the court order transfer to another district on [its] own motion"). But cf. United States v. Stratton, 649 F.2d 1066, 1077 (5th Cir. 1981) (rejecting district court's creation of judicial-convenience exception to defendant's right to venue, but leaving open possibility that "a defendant's right to venue is not absolute").

${ }_{20}$ See, e.g., United States v. DiJames, 731 F.2d 758, 761-62 (11th Cir. 1984); cf. Delaney v. United States, 199 F.2d 107, 116 (1st Cir. 1952) (right to venue is solely intended to benefit defendant). For a criticism of this view, see infra notes 56-84 and accompanying text.

${ }^{30}$ See, e.g., United States v. Abbott Laboratories, 505 F.2d 565, 572 (4th Cir. 1974), cert. denied, 420 U.S. 990 (1975); United States v. Means, 409 F. Supp. 115, 116-17 (D.N.D. 1976); see also Parr v. United States, 351 U.S. 513, 523 (1956) (Warren, C.J., dissenting) ("Rule 21 of the Federal Rules of Criminal Procedure allows defendants to obtain changes of venue in order to get fair and impartial trial. No rule or statute grants such a privilege to the United States.").

The federal rules themselves are based on the assumption that the sixth amendment requires that only the defendant be able to waive his right to venue. See FED. R. CRIM. P. 21(a) advisory committee note ("[Rule 21 (a)] provides for a change of venue only on defendant's motion and does not extend the same right to the prosecution, since the defendant 


\section{B. The Case Law}

Once it is assumed that only the defendant can move for a change of venue, a court is faced with the task of reconciling the conflict that may arise when a defendant insists on both his right to venue and his right to an impartial jury. In doing so, lower federal courts have developed two approaches: (1) dismissing the case and (2) creating an implicit presumption that the jury in the district where the crime was committed is impartial. ${ }^{31}$ Neither solution, however, withstands analysis.

1. Dismissal of the Case. At least one federal court has held that the sixth amendment requires that the case be dismissed when a defendant stands on his venue right in the face of publicity that will result in a partial jury. ${ }^{32}$ In United States v. Cotton ${ }^{33}$ the

has a constitutional right to a trial in the district where the offense was committed.") (citations omitted). For a discussion of the relationship between these rules and the problem examined in this comment, see infra notes 98-100 and accompanying text.

s1 In addition to the court-ordered change of venue proposed by this comment, see infra notes 85-100 and accompanying text, courts confronted with the conflict between a defendant's right to venue and his right to an impartial jury might have considered two other approaches: a court-ordered waiver either of the right to a speedy trial or the right to trial by jury. A court-ordered waiver of a defendant's right to a speedy trial would be inappropriate: although the defendant's partial responsibility for the delay has been held to justify extending the constitutionally permissible period of delay, see, e.g., United States v. Askew, 584 F.2d 960, 962 (10th Cir. 1978), cert. denied, 439 U.S. 1132 (1979); United States v. Herman, 576 F.2d 1139, 1145 \& n. 5 (5th Cir. 1978), the Supreme Court has not held that this factor is by itself sufficient to justify every delay, see, e.g., Barker v. Wingo, 407 U.S. 514,533 (1972) ("We regard none of the four factors [length of delay, reason for the delay, the defendant's assertion of his right, and prejudice to the defendant] as either a necessary or sufficient condition to the finding of a deprivation of the right of speedy trial.").

Neither have courts used the second alternative-a court-ordered bench trial-to solve the conflict. Because a defendant's right to trial by jury is "fundamental to the American scheme of justice," Duncan v. Louisiana, 391 U.S. 145, 149 (1968); see also Patton v. United States, 281 U.S. 276, 297 (1930) (framers intended that "the right of trial by jury should remain inviolable"), the Supreme Court has held that "[i]n the absence of a valid consent the district court cannot proceed except with a jury," Patton, 281 U.S. at 299. In fact, the Court has considered the right to a jury trial to be so important that a defendant's waiver of this right will not be effective without the consent of the court and the government. See Singer v. United States, 380 U.S. 24, 36-37 (1965) (upholding the constitutionality of FED. R. CRIM. P. 23(a) that requires such consent). As a result, lower federal courts have not adopted a court-ordered waiver of a defendant's right to a jury trial as a solution to this problem.

${ }^{32}$ United States v. Cotton, No. 68-CR-113 (E.D. Wis. June 11, 1969), appeal dismissed, 397 U.S. 45 (1970), reprinted in part in Transcript, supra note 22; cf. Wright, supra note 3 , at 435,438 (in the rare case where pretrial publicity renders a fair trial of the accused "impossible under any circumstances or under any safeguards," the case should be dismissed). See generally Stanga, supra note 18, at 22-23 (discussing the use of dismissals when other measures have failed to cure problems caused by prejudice in the community). A few other district courts have also adopted the dismissal-of-the-case approach in such situations but their decisions have been reversed on appeal. See, e.g., United States v. Abbott Laboratories, 369 F. Supp. 1396, 1404 (E.D.N.C. 1973), rev'd, 505 F.2d 565 (4th Cir. 1974), 
defendants had been accused of breaking into a Selective Service office in Milwaukee and burning draft records in order to protest the Vietnam War. This case, known as the trial of the "Milwaukee 14," generated extensive prejudicial pretrial publicity. ${ }^{34}$ After conducting an exhaustive voir dire of 142 potential jurors, the district court concluded that the adverse pretrial publicity prevented the defendants from receiving "a completely fair and impartial" trial in the Eastern District of Wisconsin at that time. ${ }^{35}$ Because the defendants had refused to move for a change of venue and because the grant of a continuance would violate their right to a speedy trial, the court held that the case had to be dismissed..$^{36}$

Other courts have been reluctant to dismiss cases in such situations. ${ }^{37}$ Their reluctance can be justified on two grounds. First, the dismissal approach is based on the conclusion that when two constitutional rights come into conflict, the defendant cannot be forced to waive one of them. The Supreme Court, however, has generally concluded that the government may condition the exercise of one constitutional right on the relinquishment of another if this would not significantly impair the purposes underlying each right. ${ }^{38}$ Under the testimonial-waiver doctrine, for example, the

cert. denied, 420 U.S. 990 (1975); cf. United States ex rel. Brown v. Smith, 200 F. Supp. 885, 933 (D. Vt.) (suggesting the availability of dismissal where an impartial jury cannot be obtained), rev'd, 306 F.2d 596 (2d Cir. 1962).

${ }^{33}$ No. 68-CR-113 (E.D. Wis. June 11, 1969), appeal dismissed, 397 U.S. 45 (1970), reprinted in part in Transcript, supra note 22.

${ }^{34}$ See Transcript, supra note 22, at 102, 105; see also 1970 WIS. L. REv. 209, 209-10 (discussing the pretrial publicity the case received).

3s Transcript, supra note 22 , at 105.

${ }^{36} \mathrm{Id}$. at $102-05$.

${ }^{37}$ See, e.g., United States v. Abbott Laboratories, 505 F.2d 565, 572 (4th Cir. 1974) (discussed infra notes 43-50 and accompanying text), cert. denied, 420 U.S. 990 (1975); United States v. Delaney, 199 F.2d 107, 111-12 (1st Cir. 1952) (concluding that it was not reversible error to reject a motion for dismissal because the "publicity was [not] so permanent, and ineradicable by mere lapse of time, that the court should have recognized the impossibility of a fair trial ever being held at any time within the foreseeable future"); United States v. Hubbard, 474 F. Supp. 64, 77-78 (D.D.C. 1979) (dismissal not considered because defendant had moved neither for a continuance nor a change of venue); United States v. Zovluck, 274 F. Supp. 385, 389-90 (S.D.N.Y. 1967) (dismissal rejected because prejudicial publicity "unlikely . . . to have any lasting influence"); cf. United States ex rel. Means v. Solem, 457 F. Supp. 1256, 1261-65 (D.S.D. 1978) (in habeas corpus case, examination of several thousand pages of voir dire transcripts convinced court that petitioner had not established his inability to get a fair trial even though state trial court had dismissed charges arising out of the same incident).

${ }^{38}$ In Simmons v. United States, 390 U.S. 377 (1968), the Supreme Court adopted an absolute approach, in a case involving a conflict between the defendant's ability to assert his fourth amendment right to have evidence suppressed and his fifth amendment right against self-incrimination, on the ground that it is "intolerable that one constitutional right should have to be surrendered in order to assert another," $i d$. at 394 . In subsequent cases, however, 
Court has concluded that a defendant who exercises his constitutional right to testify in his own defense must relinquish his fifth amendment privilege against self-incrimination with respect to cross-examination reasonably related to his direct testimony. ${ }^{39}$ The Court has justified this conclusion on the ground that giving a defendant "immunity from cross-examination on the matters he has himself put in dispute. . . . would make of the Fifth Amendment not only a humane safeguard against judicially coerced self-disclosure but a positive invitation to mutilate the truth a party offers to tell." ${ }^{40}$ In other words, when different constitutional rights come into conflict, the Court has resolved the tension, not by creating a per se rule that a defendant must be guaranteed both rights, but by examining the purposes underlying these rights and adopting the approach that best accommodates the purposes of each one.

Another objection to the Cotton dismissal approach is that it imposes substantial costs on society by frustrating the important societal interest in trying people who have been accused of committing crimes. ${ }^{41}$ This problem is particularly acute in cases of ex-

the Court has abandoned the Simmons per se rule in favor of a balancing approach that focuses on an examination of the underlying purposes of each constitutional right. See, e.g., Jenkins v. Anderson, 447 U.S. 231, 236-38 (1980) (because the "Constitution does not forbid 'every government-imposed choice in the criminal process that has the effect of discouraging the exercise of constitutional rights," " the proper approach is to determine whether the compelled election would significantly impair any of the policies underlying the rights involved) (quoting Chaffin v. Stynchcombe, 412 U.S. 17, 30 (1973)); McGautha v. California, 402 U.S. 183, 213 (1971) ("The threshold question is whether compelling the election impairs to an appreciable extent any of the policies behind the rights involved."). For different approaches to the problem presented by a conflict between the constitutional rights of a defendant, see Westen, Incredible Dilemmas: Conditioning One Constitutional Right on the Forfeiture of Another, 66 Iowa L. REv. 741, 753-58 (1981) (arguing that the constitutionality of a compelled election is best resolved by simply "balancing the state's interest in compelling the election against the individual's interest in being relieved of the election"); White, The Psychiatric Examination and the Fifth Amendment Privilege in Capital Cases, 74 J. Crim. L. \& Criminology 943, 950-58 (1983) (concluding that the proper approach is "to assess whether the two rights involved in the compelled election are incompatible in the sense that the defendant's exercise of both will have the effect of diminishing the scope which should be afforded at least one of the two rights") (footnote omitted).

${ }^{39}$ See Brown v. United States, 356 U.S. 148, 155-57 (1956); see also Jenkins v. Anderson, 447 U.S. 231, 238 (1980) ("Once a defendant decides to testify, '[t]he interests of the other party and regard for the function of courts of justice to ascertain the truth become relevant, and prevail in the balance of considerations determining the scope and limits of the privilege against self-incrimination.' ") (quoting Brown, 356 U.S. at 156). See generally Edward Cleary, McCormick on Evidence $\S 132$ (3d ed. 1984) (discussing the testimonialwaiver doctrine).

to Brown v. United States, 356 U.S. 148, 156 (1956).

11 See, e.g., Barker v. Wingo, 407 U.S. 514, 522 n.16 (1972) (noting that the "overzealous application of [the dismissal] remedy would infringe the societal interest in trying people accused of crime" ") (quoting United States v. Ewell, 383 U.S. 116, 121 (1966)); infra 
tensive pretrial publicity because dismissing these cases will often result in the freeing of those defendants whom society would most like to see tried. In addition, frequent grants of dismissal in cases where there has been adverse pretrial publicity would create an incentive for defendants to refuse to take measures that would prevent jury partiality: defendants who would ordinarily move for a change of venue in order to avoid the risk of a partial jury might instead insist on their right to venue in the hope that their cases would be dismissed.

2. Presumption of Impartiality. In order to avoid the problems created by dismissing the case, most lower federal courts have responded to the conflict created by a defendant who asserts both his right to venue and his right to an impartial jury by presuming that if the defendant refuses to move for a change of venue, the jury in the district where the crime was committed is impartial. ${ }^{42}$ In United States $v$. Abbott Laboratories, ${ }^{43}$ for example, the defendants had been prosecuted in the Eastern District of North Carolina for the distribution in interstate commerce of adulterated and misbranded drugs. Prior to trial, the media had run numerous inflammatory stories accusing the defendants of causing the deaths of individuals who had used the contaminated drugs. ${ }^{44}$ The district court concluded that the pretrial publicity had caused such prejudice within the district that voir dire and a continuance could not ensure the selection of an impartial jury. ${ }^{45}$ Because the defendants had opposed a change of venue, the district court held that the sixth amendment required the case to be dismissed. ${ }^{48}$

In reversing the district court's decision to dismiss the case, the Fourth Circuit addressed the problem of a defendant who ref-

notes 56-84 and accompanying text (arguing that the sixth amendment right to venue is in part intended to protect the government's interest in trying those accused of committing crimes); $c f$. United States v. Leon, $104 \mathrm{~S}$. Ct. 3405, 3413 (1984) (noting that the exclusionary rule, by allowing some guilty defendants to go free, imposes a "substantial" cost on society); Tibbs v. Florida, 457 U.S. 31, 40 (1982) (in double jeopardy cases, "society would pay too high a price "were every accused granted immunity from punishment because of any defect sufficient to constitute reversible error in the proceedings leading to conviction" ") (quoting United States v. Tateo, 377 U.S. 463, 466 (1964)).

42 See, e.g., cases cited supra note 37.

43 505 F.2d 565 (4th Cir. 1974), cert. denied, 420 U.S. 990 (1975).

"For example, a local television station had broadcast a news report stating that nine deaths and four hundred illnesses had been attributed to contaminated drugs manufactured by the defendants' company. 505 F.2d at 568-69.

t5 United States v. Abbott Laboratories, 369 F. Supp. 1396, 1403-04 (E.D.N.C. 1973), rev'd, 505 F.2d 565 (4th Cir. 1974), cert. denied, 420 U.S. 990 (1975).

${ }^{\wedge} 369$ F. Supp. at 1404-05. 
uses to waive his right to venue despite the existence of pervasive prejudice against him in the district where the crime was committed. ${ }^{47}$ Although the court suggested that a dismissal might be proper in cases where "prejudicial pretrial publicity is so widespread and pervasive that a change of venue would be ineffective to assure a defendant a fair trial,"48 it nevertheless concluded that a defendant who has "unused means" to protect his right to an impartial jury should not be granted a dismissal unless he makes "a conclusive showing that the unused means would be ineffective." 49 The necessary result of the holding in Abbott is that defendants must show not only that they could not receive a trial by an impartial jury in the district where the crime was committed but also that they could not receive one in any other district in the country even if they did move for a change of venue. If they cannot make such a showing, they must be tried in the original district. Since cases of nationwide prejudice are extremely rare, ${ }^{50}$ a defendant's refusal to move for a change of venue would in effect be dispositive of the question whether an impartial jury could be selected in the district where the crime was committed.

Under the presumption-of-impartiality approach, courts have resolved the conflict between the right to an impartial jury and the right to venue by in effect "waiving," without the defendant's consent, the right to an impartial jury. This result can be criticized on two grounds. First, the presumption-of-impartiality approach rests on the premise that a defendant's right to venue, but not his right to an impartial jury, is an absolute right of the defendant that only

47505 F.2d at 571-73.

48 Id. at 571-72 (discussing Rideau v. Louisiana, 373 U.S. 723 (1963)).

405 F.2d at 572:

Although a change of venue under Rule 21 cannot be imposed on a defendant against his will, the availability of a change of venue as a corrective device undergirds the requirement that a defendant, who declines to request a change of venue but who seeks dismissal of an indictment against him because of allegedly prejudicial pretrial publicity, demonstrate the existence of actual prejudice far more convincingly than was done in the case at bar. A defendant who has unused means to protect his rights should not lightly be granted the extreme remedy of dismissal of the charges against him on less than a conclusive showing that the unused means would be ineffective.

so Even in a case involving some of the Watergate defendants, United States v. Haldeman, 559 F.2d 31 (D.C. Cir. 1976), the majority and the dissent disagreed about whether nationwide prejudice existed. The majority concluded that a change of venue would have been of "only doubtful value" because prejudice against the defendants was nationwide. $I d$. at 64 n.43. The dissent, however, relied on a series of surveys showing that while $93 \%$ of the Washington, D.C., population had heard about the indictments and $73 \%$ had formed an opinion as to the defendants' guilt or innocence, only $50 \%$ in nearby Richmond, Virginia, and $43 \%$ nationwide had formed an opinion. Id. at 144-45 (MacKinnon, J., dissenting). This suggests that cases of nationwide prejudice are very rare. 
he can waive. As will be shown below, however, this assumption is unjustified in light of the purposes of the right to venue.

Moreover, the presumption-of-impartiality approach is particularly troubling because it requires the "waiver" of the right to an impartial jury, which is central to the fair and accurate disposition of criminal proceedings, ${ }^{51}$ in order to protect the right to venue, which only indirectly ensures the fairness and accuracy of the trial by preventing the government from unduly inconveniencing the defendant or engaging in "jury-shopping." In Irvin v. Dowd, ${ }^{53}$ for example, the Supreme Court stressed the importance of an impartial jury:

In essence, the right to jury trial guarantees to the criminally accused a fair trial by a panel of impartial, "indifferent" jurors. . . . "A fair trial in a fair tribunal is a basic requirement of due process." ... In the ultimate analysis, only the jury can strip a man of his liberty or his life. In the language of Lord Coke, a juror must be as "indifferent as he stands unsworne." . . . His verdict must be based upon the evidence developed at the trial. ${ }^{54}$

By creating a presumption of impartiality in the district where the crime was committed, these courts have resolved the tension between these two rights at the expense of the fairness and accuracy of the trial.

\section{A Reexamination of the Sixth Amendment Venue REQUIREMENT}

In resolving the problem presented by a defendant who insists on his right to venue in circumstances in which a change of venue is necessary to protect his right to an impartial jury, both ap-

s1 See, e.g., Nebraska Press Ass'n v. Stuart, 427 U.S. 539, 551-55 (1976) (right to " "trial by jury in criminal cases is fundamental to the American scheme of justice" "and includes the right to impartial jurors) (quoting Duncan v. Louisiana, 391 U.S. 145, 149 (1968)); Groppi v. Wisconsin, 400 U.S. 505, 509 (1971) ("the right to jury trial guarantees to the criminally accused a fair trial by a panel of impartial . . . jurors" ") (quoting Irvin v. Dowd, 366 U.S. 717, 722 (1961)); see also Nebraska Press Ass'n, 427 U.S. at 586 (Brennan, J., concurring) ("[The right to trial by an impartial jury] is a right essential to the preservation and enjoyment of all other rights, providing a necessary means of safeguarding personal liberties against government oppression.").

s2 See infra notes 58-64 and accompanying text.

${ }^{63} 366$ U.S. 717 (1961).

s4 Id. at 722 (quoting In re Murchison, 349 U.S. 133, 136 (1955); EDWARD CoKE, A CoMMENTARY UPON LITTLETON 155b (15th ed. London 1794) (1st ed. London 1628)) (citations omitted). 
proaches-dismissing the case and the presumption of impartiality-have assumed that the sixth amendment confers an absolute right to venue that only the defendant can waive. ${ }^{55}$ Further analysis of the history and purposes of the sixth amendment right to venue shows, however, that this assumption is incorrect.

\section{A. The Purpose of the Sixth Amendment Right to Venue}

Article III, section 2, clause 3 of the Constitution requires that "[t]he Trial of all Crimes, except in Cases of Impeachment, shall be ... held in the State where the said Crimes shall have been committed." Although this provision generated little discussion during the Constitutional Convention, it was probably a response to the English practice in the late 1760's and 1770's of transporting colonists to another colony or to England for trial. ${ }^{.7}$ The colonists had vehemently protested that this practice prevented defendants from presenting an adequate defense and allowed the English government to obtain juries sympathetic to its position. ${ }^{58}$ In order to correct this abuse, the article III venue provision limited the federal government's choice of forum for trial to the state in which the crime was committed.

At the ratifying conventions, however, this provision was severely criticized. ${ }^{59}$ First, opponents argued that it was inadequate

Ss See supra notes 28-30 and accompanying text.

so U.S. CoNsT. art. III, § 2, cl. 3.

s7 See, e.g., Kershen, supra note 2, at 805-08; Comment, Multi-Venue and the Obscenity Statutes, 115 U. PA. L. REv. 399, 408-10 (1967).

ss For example, the Virginia House of Burgesses in 1769 issued the following proclamation:

$[\mathrm{H}]$ ow truly deplorable must be the Case of a wretched American, who having incurred the Displeasure of anyone in Power is dragged from his native Home, and his dearest domestic Connections, thrown into Prison, not to await his Trial before a Court, Jury or judges, from a Knowledge of whom he is encouraged to hope for speedy justice; but to exchange his Imprisonment in his own Country for fetters among Strangers? Conveyed to a distant Land, where no Friends, no Relation, will alleviate his Distress, or minister to his Necessities, and where no Witness can be found to testify to his Innocence. . . .

Journats of THE House of Burgesses 1766-1769, at 216 (J. Kennedy ed. 1906); see also 1 The Bill of Rights: A Documentary History 210 (B. Schwartz ed. 1971) (Samuel Adams protested that "whether condemned or acquitted [the accused] will probably be ruined by the expense attending the tryal, and his long absence from his Family and business.").

so Critics of the article III provision offered two other objections. First, they argued that because federal appellate courts would have the power to review findings of both law and fact, the verdict of an impartial jury could be set aside with impunity. See, e.g., 3 THE Debates in the Several State Conventions on the Adoption or the Federal ConstituTION 540 (J. Elliott ed. Washington 1854) (1st ed. Washington 1830) (statement of Patrick Henry at the Virginia ratification convention) [hereinafter cited as ErLIOTT's DEBATEs]. Sec- 
to protect a federal criminal defendant against the inconvenience and expense associated with presenting a defense far away from his place of residence.$^{60}$ For example, Abraham Holmes, a delegate to the Massachusetts ratifying convention, argued that a defendant "may, by reason of the distance of his residence from the place of the trial, be incapable of making such defense as he is, in justice, entitled to, and which he could avail himself of, if his trial was in the same county where the crime is said to have been committed." In addition, the critics also observed that this provision was so broadly drawn as to allow the federal government to engage in the "jury-shopping" that the provision was in part intended to prevent: ${ }^{62}$ because "[the defendant] may be tried in any part of the state," the government "can hang anyone they please, by having a jury to suit their purpose." ${ }^{13}$ In order to protect a defendant from the possibility of inconvenience and prejudice, they proposed that the venue for federal trials be limited to the county in which the crime was committed. ${ }^{64}$

In response to these criticisms, James Madison argued at the Virginia ratifying convention that a narrow venue provision might completely prevent the government from trying the defendant. For example, he observed that in the event of a local rebellion, ${ }^{66}$ it might be impossible for the federal government to summon a jury from the venue. ${ }^{66}$ Others, however, simply defended the article III

ond, they objected to the absence of a provision for jury trial in civil cases. See, e.g., 2 THE Documentary History of tHe Ratification of the Constitution 525-26 (M. Jensen ed. 1976) (statement of John Smilie at the Pennsylvania ratification convention) [hereinafter cited as Documentary History]. See generally Comment, supra note 57, at 410.

${ }^{60}$ See, e.g., 2 Documentary History, supra note 59, at 633-34 (minority criticism at the Pennsylvania ratification convention).

B1 2 Elliotr's Debates, supra note 59, at 110 (emphasis deleted).

${ }^{62}$ See supra notes 56-58 and accompanying text.

- 3 ElliotT's DeBATES, supra note 59, at 568-69 (statement of Mr. Grayson at Virginia ratification convention). But see id. at 560 (John Marshall denigrated the fear that the federal government would "jury-shop" on the ground that the change of venue would not "carr[y] [a man] from a federal to an anti-federal corner, (and vice versa) where men are ready to destroy him.").

o4 See, e.g., 3 Elliotr's Debates, supra note 59, at 568-69 (Patrick Henry arguing at the Virginia ratification in favor of a jury of the vicinage); 2 Documentary History, supra note 59, at 634 (minority at the Pennsylvania ratification convention supported a proposal providing for an impartial "jury of the neighborhood or country").

6s Madison's fear that an insurrection might prevent the government from trying a defendant probably resulted from Shays' Rebellion. In 1786, Daniel Shays led a rebellion in Massachusetts demanding the issuance of more paper money and the passage of debtor relief laws. For four months, this rebellion "overawe[d] the courts and def[ied] the laws." 1 Francis Thorpe, The Constitutional. History of the United States 286-87 (1970).

${ }^{68}$ It was objected, yesterday, that there was no provision for a jury from the vicinage.

If it could have been done with safety, it would not have been opposed. It might so 
provision on the grounds that a narrower venue provision could not be drafted because of the great diversity of state practices in selecting juries ${ }^{67}$ and that jurors from the defendant's neighborhood were no longer necessary in a system in which juries acted as impartial weighers of evidence presented at trial and not as judges of character and personality. ${ }^{68}$

During the first session of Congress, Madison proposed a constitutional amendment that would have met the objections of the critics of the article III provision without sacrificing the government's interest in trying criminal defendants. He suggested that the trial of all crimes (except impeachment and certain military offenses) "shall be by an impartial jury of freeholders of the vicinage ... provided that in cases of crimes committed within any county which may be in possession of an enemy, or in which a general insurrection may prevail, the trial may by law be authorized in some other county of the same State, as near as may be to the seat of the offense."

happen that a trial would be impracticable in the country. Suppose a rebellion in a whole district; would it not be impossible to get a jury? . . . It must be, therefore, left to the discretion of the legislature to modify it according to circumstances. This is a complete and satisfactory answer.

3 ElliotT's Debates, supra note 59, at 537. In a proposed amendment to the Constitution, the New York ratification convention also expressed concern about the possibility of a local rebellion preventing the trial of persons accused of crime:

[T] he trial of all crimes cognizable by the judiciary of the United States . . . should be ... by an impartial jury of the county where the crime was committed .... But in cases of crimes . . . committed within any county in which a general insurrection may prevail . . . the inquiry and trial may be in such county as the Congress shall by law direct; which county ... . should be as near as conveniently may be to that county in which the crime may have been committed . . .

1 id. at 328.

Others, however, disagreed with Madison's conclusion that the danger of an insurrection prevented the venue provision from being defined more narrowly:

I beg leave to differ from my honorable friends in answering this objection. They said that, in case of a general rebellion, the jury was to be drawn from some other part of the country. I know that this practice is sanctified by the usages in England. But I always thought that this was one of those instances to which the nation, though alive to liberty, had unguardedly submitted.

3 id. at 574 (statement of Governor Randolph at Virginia ratification convention); see also id. at 545 (Patrick Henry argued that "[j] uries from the vicinage being not secured, this right is in reality sacrificed. All is gone. And why? Because a rebellion may arise. . . . I trust the honorable gentlemen . . . will be sorry for this observation.").

67 See, e.g., F. HELLER, supra note 2, at 27.

es See, e.g., 2 ElliotT's Debates, supra note 59, at 112-13 (statement of Christopher Gore at Massachusetts ratification convention); 3 id. at 546-47 (statement of Edmund Pendleton at Virginia ratification convention); 4 id. at 150 (statement of Governor Johnston at North Carolina ratification convention).

- 1 Annals or Cong. 452 (J. Gales ed. 1789). 
After some initial opposition, ${ }^{70}$ the House of Representatives adopted Madison's proposal with several minor modifications: (1) the word "county" was changed to the less definite word "place"; (2) the condition which permitted a change of venue was simply an "insurrection," not a "general insurrection"; and (3) venue could be changed to anywhere within the state, not necessarily "as near as may be to the seat of the offence." ${ }^{11}$ By giving courts more freedom to choose where the trial would occur, these modifications indicate that the House of Representatives accepted Madison's concern about the dangers of a narrow, inflexible venue provision.

The Senate initially eliminated the entire venue provision from Madison's proposed amendment. ${ }^{72}$ Although no record of the Senate's discussion survives, ${ }^{73}$ a letter from James Madison to Edmund Pendleton states that the Senate had eliminated the venue provision on the grounds that the term "vicinage" was "either too vague or too strict a term, too vague if depending on limits to be fixed by the pleasure of the law, too strict if limited to the County" and that the different state practices in selecting juries prevented an agreement on the proper geographical area. ${ }^{74}$ This suggests that the Senate rejected Madison's venue provision not because it disagreed about the importance of protecting the government's interest in trying persons accused of crime but rather because it feared that his proposal was too narrow to achieve this purpose and because it would also require the restructuring of jury-selection procedures in many states. ${ }^{75}$

70 Representative Burke of South Carolina proposed that the word "vicinage" be replaced by "district or county within which the offense was committed," but his proposal was apparently defeated. 1 AnNals of Cong. 789 (J. Gales ed. 1789); see also Comment, supra note 57 , at 411 .

71 Annals of Cong. 788-89 (J. Gales ed. 1789).

${ }^{72}$ See Kershen, supra note 2, at 822.

${ }^{73}$ Senator William Maclay of Pennsylvania, whose journal is the principal source of information on Senate proceedings during the first session of Congress, was ill during the period when this amendment was debated. See F. Heller, supra note 2, at 31 .

7 Letter from James Madison to Edmund Pendleton (Sept. 23, 1789), reprinted in 12 The Papers of James Madison 419 (C. Hobson \& R. Rutland ed. 1979). In another letter, Madison observed:

[The Senate] sent back the plan of amendments with some alterations which strike in my opinion at the most salutary articles. In many of the States juries even in criminal cases, are taken from the State at large-in others, from districts of consider[able] extent-in a very few from the County alone.

Letter from James Madison to Edmund Pendleton (Sept. 14, 1789), reprinted in 12 THE PAPERS of JAMES MAdison, supra, at 402.

${ }^{75}$ Cf. Kershen, supra note 2, at 823-25 (suggesting that Federalist senators might have rejected Madison's proposal for fear that if " 'vicinage' meant that jurors would be [selected] from the inhabitants of the county where the crime was committed, . . a local leader of 
After the dispute was referred to a conference committee, Congress agreed to a compromise, which eventually became the sixth amendment, under which the trial of federal criminal defendants would be "by an impartial jury of the State and district . . . which district shall have been previously ascertained by law." $\mathrm{Al}$ though the text of the sixth amendment does not expressly incorporate either Madison's proposal or his concern that the government might not be able to try criminal defendants in certain circumstances, the available evidence suggests that Congress had adopted this formulation as a compromise between Madison's proposal and the original article III provision in order to protect both the defendant's and the government's interests. ${ }^{77}$

The Judiciary Act of $1789,{ }^{78}$ which was passed one day before the Bill of Rights was sent to the states for ratification, also supports this interpretation of the sixth amendment. ${ }^{79}$ In section 29 of the Judiciary Act, Congress required that all capital crimes ${ }^{80}$ be tried in the county where the crime was committed but included an exception that allowed a change of venue if there was "great inconvenience" in the county. ${ }^{81}$ In such a case, the trial would take place outside the county (but within the state), and at least twelve prospective jurors would have to be summoned from the county where the crime had been committed. Hence, in cases involving capital crimes, Congress had considered Madison's fear that a narrow venue requirement would inadequately protect the government's interest in trying criminal defendants and adopted his solution.

rebellion might be protected by local jurors" and out of a belief that the art. III provision had been sufficient protection for the defendant's right to venue).

76 Annals of Cong. 948 (J. Gales ed. 1789).

${ }_{77}$ Cf. Heller, supra note 2, at 93 ("The wording of the amendment represented a com. promise between the localist tendencies of those who wished to restrict vicinage to the county and the Federalists who urged a minimum of restraint in the exercise of the judicial power of the national government.").

78 Judiciary Act of 1789, ch. 20, 1 Stat. 73.

79 See, e.g., Ruthenberg v. United States, 245 U.S. 480, 482 (1918) (relying on the Judiciary Act as a "contemporary construction" of the sixth amendment). For a detailed discussion of the relationship between the sixth amendment and the Judiciary Act of 1789 , see Kershen, supra note 2, at 844-60.

Capital crimes included treason, murder, piracy, robbery on the high seas, accessory before the fact to piracy, counterfeiting, and uttering a counterfeit public security. Act of Apr. 30, 1790, ch. 9, 1 Stat. 112.

si Judiciary Act of 1789 , ch. $20, \S 29$, I Stat. 73,88 . The term "great inconvenience" has been interpreted to include rebellions in the county, see United States v. Insurgents, 26 F. Cas. 498, 499 (C.C.D. Pa. 1799) (No. 15,442); Case of Fries, 9 F. Cas. 826, 846 (C.C.D. Pa. 1799) (No. 5126), as well as other factors that inconvenience the government, see Orfield, Venue of Federal Criminal Cases, 17 U. PrTT. L. REv. 375, 404 (1956). 
Moreover, in cases involving noncapital crimes, ${ }^{82}$ Congress went even further and provided that the trial would take place in the district where the crime was committed. ${ }^{83}$ Since Congress (with two exceptions) defined the boundaries of the districts as coextensive with the boundaries of the states, ${ }^{84}$ venue was defined even more broadly than it had been in Madison's proposal. By equating districts with states, Congress had attempted to ensure that the government's interest in trying a defendant would not be sacrificed to the defendant's right to venue.

The history and purposes of the sixth amendment therefore suggest that the right to venue is not an absolute right of the defendant. While the sixth amendment right to venue was intended to protect a defendant against inconvenience and prejudice, this was not its only purpose; the framers also intended to protect the government's interest in trying a person accused of crime in an impartial environment.

\section{B. A Court-Ordered Change of Venue}

Although the framers reconciled the right to venue with the right to an impartial jury, social change has resurrected the tension between these rights. The development of the mass media has had a significant impact on the courts' ability to impanel an impartial jury in the district where the crime was committed. ${ }^{85}$ Reduction in the size of judicial districts has also increased the risk that an impartial jury cannot be found in the district. ${ }^{86}$

82 Noncapital crimes included misprision of treason, misprision of felony, manslaughter, accessory after the fact to piracy, stealing or falsifying court records or court processes, larceny, embezzlement, perjury, bribery, obstruction of court processes, and receiving stolen property. Act of Apr. 30, 1790, ch. 9, 1 Stat. 112.

${ }_{83}$ Judiciary Act of 1789, ch. 20, § 29, 1 Stat. 73, 88; see also Warren, New Light on the History of the Federal Judiciary Act of 1789, 37 HaRv. L. REv. 49, 106 (1923).

84 Judiciary Act of 1789 , ch. $20, \S 2,1$ Stat. 73, 73. (Massachusetts and Virginia were each divided into two districts).

ss See, e.g., Goldfarb, supra note 19, at 821 ("The all-pervasive nature of modern mass media renders the traditional instruments for insuring a fair trial of questionable value."); cf. Irvin v. Dowd, 366 U.S. 717, 722 (1961) ("In these days of swift, widespread and diverse methods of communication, an important case can be expected to arouse the interest of the public in the vicinity....").

${ }^{88}$ In order to make trials more convenient for defendants and to alleviate the problem of crowded dockets, see Surrency, Federal District Court Judges and the History of Their Courts, 40 F.R.D. 139, 148, 172 (1966), Congress has divided some states into a number of judicial districts: at present, twenty-four states have more than one district, with three states having four districts, nine states having three districts, and twelve states having two districts, see 28 U.S.C.A. §§ 81-131 (West Supp. 1985).

Improvements in transportation have had a functionally similar effect. "In terms of time and distance the present districts are therefore much smaller than those established by 
An examination of the underlying purposes of the sixth amendment suggests a resolution of the conflict between the right to venue and the right to an impartial jury: the trial should be held in the district where the crime was committed, but if prejudicial publicity prevents the trial of that defendant in that district, the court should have the power to order a change of venue to another district. ${ }^{87}$ Although the framers of the sixth amendment could not anticipate the role of the mass media in preventing the selection of an impartial jury in the district, a court-ordered change of venue best accommodates the purposes underlying the right to venue and the right to an impartial jury.

Since the defendant will be tried by an impartial jury in the district to which the case is transferred, this approach guarantees the right to an impartial jury. Moreover, the purposes underlying the right to venue are not significantly impaired. First, the societal interest in trying individuals accused of crimes $^{88}$ is vindicated because the defendant will be tried in another district and may not insist on two rights simply for the purpose of preventing the government from prosecuting him at all. Second, the framers' concerns about possible inconvenience and prejudice to the defendant are not as strongly implicated today by a change of venue outside the district. While a court-ordered change of venue would still inconvenience the defendant to some extent, it is much easier for him to undertake his defense in another district today than it would have been in $1789 .{ }^{89}$ It is also important to remember that even those trials authorized in 1789 imposed significant costs and inconvenience on defendants: first, the state-wide districts estab-

the apportionment of the Judiciary Act of 1789." F. Heller, supra note 2, at 94. At the time the Constitution was drafted, a trip from New York to Boston took five days, a journey from Boston to Savannah took $221 / 2$ days, and the distant points of the interior were a four to five weeks' trip from almost any point on the east coast. Id.

87 Under state constitutional provisions similar to the sixth amendment venue provision, courts have disagreed on the question of whether a change of venue can be ordered, without the defendant's consent, in such a situation. Compare, e.g., Mast v. Superior Court, 102 Ariz. 225, 226, 427 P.2d 917, 918 (1967) (court-ordered change of venue upheld because right to an impartial jury of the county secured by the state constitution is "conditioned upon the possibility of empanelling 'an impartial jury' in that county"), with, e.g., Blume v. State, 244 Ind. 121, 125 n.2, 189 N.E.2d 568, 570 n.2 (1963) (because state constitution provides accused with the right to trial by an impartial jury of the county, "[i]t is elementary that there is [no authorization for the prosecution or court] to take a change of venue from the county"). See generally 14 S.D.L. REv. 396 (1969) (discussing the circumstances in which a court-ordered change of venue does not infringe the right to venue under state constitutions).

see supra notes $41,65-84$ and accompanying text.

so See supra note 86 and accompanying text. 
lished by Congress in 1789 often required defendants to travel considerable distances; ${ }^{90}$ and second, since the sixth amendment guarantees a defendant the right to be tried in the district where the crime was committed, not in the district where he resides, he still might be tried far away from his home and his family. ${ }^{91}$ This suggests that while the framers were concerned about the possibility that defendants might be inconvenienced by trial far away from their residences, this factor was not the primary purpose of the right to venue. Finally, the costs and inconvenience imposed on the defendant by a court-ordered change of venue can be reduced by requiring the court to transfer the case to the nearest district where an impartial jury can be selected. ${ }^{92}$ In many cases, this requirement will result in the transfer of the case to another district within the state (if it is a multidistrict state) or to a district in an adjoining state..$^{93}$

The danger of jury prejudice against a defendant from an adjoining state has probably diminished because the development of a well-established national identity in the last two hundred years

9o See supra notes 84,86 and accompanying text.

${ }^{91}$ See, e.g., Platt v. Minnesota Mining \& Mfg. Co., 376 U.S. 240, 245-46 (1964) ("home" of the offender does not determine venue); Travis v. United States, 364 U.S. 631, 634 (1961) (trial can be "at a distant place" because the "constitutional requirement is as to the locality of the offense and not the personal presence of the offender" ") (quoting Armour Packing Co. v. United States, 205 U.S. 56, 76 (1908)); Johnston v. United States, 351 U.S. 215, 220-21 (1956) ("[V]ariation . . . [from the rule that the situs of the trial is determined by the vicinage of the crime and not the residence of the accused] for convenience of the prosecution or the accused is not justified.").

${ }_{82}$ This was indeed the limitation included in proposals governing venue that preceded the ratification of the sixth amendment. See supra note 66 (proposed amendment from New York ratifying convention); supra text accompanying note 69 (amendment proposed by James Madison).

If the defendant shows that there exists in the district to which the case has been transferred "so great a prejudice against the defendant that he cannot obtain a fair and impartial trial," FED. R. CRIM. P. 21(a), he is of course entitled to move for a change of venue to another district.

9s Empirical studies have suggested that impartial juries can usually be found somewhere within a state. See, e.g., FaIR Trial Standards, supra note 12, at 120-21, 183-84 ("[I]t is frequently true that a case which will receive intensive coverage in one locality will scarcely be noticed in another, particularly when the state is a large one with more than one principal city."). For example, a crime that has generated a lot of controversy in a primarily rural district would probably not generate the same degree of publicity if it were transferred to a large city in another district. See, e.g., id. at 184 ("[A]lmost all state criminal reporting has much less prominence and uniqueness in the large cities studied than in the less urban areas where the stories often originate."); Stanga, supra note 18, at 21 ("[C]hange of venue [is an] effective remedy against community prejudice when the original forum is in a rural area or a small town.") (footnote omitted); Taylor, Crime Reporting and Publicity of Criminal Proceedings, 66 CoLum. L. Rev. 34, 53 (1966) (publicity threatening jury impartiality tends to be localized). 
has made it less likely that a jury from Maryland would convict a defendant from Virginia solely on the ground that he was from Virginia. ${ }^{94}$ The possibility still exists, however, that the government might abuse the power to transfer the case outside the district in order to shop for a jury that would be sympathetic to its position.95 This danger can be reduced in the present situation by requiring the court to order a change of venue when it determines that an impartial jury cannot be found in the district and the defendant refuses to waive his right to venue. Since the court is a neutral arbiter, not an adversarial party, this requirement will ensure that a change of venue is not ordered to obtain a tactical advantage for the government.

This approach-a court-ordered change of venue to another district when an impartial jury cannot be selected in the district where the crime was committed-more properly aligns the sixth amendment rights to-venue and an impartial jury with the framers' intent than does either of the judicial approaches discussed above. ${ }^{96}$ Unlike the dismissal of all cases in which an impartial jury cannot be found in the district, this approach would vindicate the important societal interest in having an impartial trial of defendants accused of crime. At the same time, this approach would not dilute the defendant's right to an impartial jury, which is the essence of a fair trial: ${ }^{97}$ the defendant will receive a trial by an impartial jury in the place to which the trial is transferred.

A final objection to a court-ordered change of venue is that it would conflict with Rules 18 and 21(a) of the Federal Rules of Criminal Procedure, ${ }^{98}$ which limit the right to move for a change of venue to the defendant himself. A literal and strict application of these rules, however, would be improper in this context. There is no indication that the draftsmen of these procedural rules considered the possibility that an impartial jury could not be found in the district where the crime was committed and nevertheless intended for the case to be tried in that district. ${ }^{99}$ Most important,

o4 Cf. David Currie, Fedrral Courts 252-53 (3d ed. 1982) (although local bias is the common justification for diversity jurisdiction, there is little evidence of actual bias against nonresident litigants in diversity cases).

${ }^{95}$ See supra notes 56-58 and accompanying text.

96 See supra notes 32-54 and accompanying text.

${ }^{\circ 7}$ See supra notes 51, 53-54 and accompanying text.

28 FED. R. Crim. P. 18, 21(a) (discussed supra note 30 and accompanying text).

- In fact, the draftsmen of Rule 21(a) expressly provided that only a defendant could move for a change of venue because of their belief that the sixth amendment right to venue requires this result. See supra note 30 . 
as demonstrated above, ${ }^{100}$ a court-ordered change of venue is constitutionally required in order to resolve the problem created by a defendant who insists on his right to venue in cases in which a change of venue is the only remedy that will ensure his right to an impartial jury.

\section{ConcLusion}

This comment has examined the problem created by a criminal defendant's refusal to waive his right to trial in the district where the crime was committed when a change of venue is necessary to protect his right to an impartial jury. The approaches developed by the federal courts-dismissal of the case and dilution of the impartial-jury requirement through the creation of a presumption of impartiality-either infringe important societal interests or improperly "waive," without the defendant's consent, the right to an impartial jury. But these are not the only two options available. Both approaches assume that a criminal defendant's right to venue is an absolute right that only he can waive, but an examination of the purposes of the sixth amendment suggests that the defendant's right to venue was conditioned by the framers upon the ability of the government to try the defendant in the venue. As a result, in cases where an impartial jury cannot be selected in the district where the crime was committed and the defendant refuses to move for a change of venue, the appropriate solution is a court-ordered change of venue to another district. Potential problems with this approach-inconvenience to the defendant and the possibility that the government might engage in "jury-shopping"-can best be solved by requiring the court to determine when an impartial jury cannot be found in the district and to transfer the case to the nearest district where an impartial jury is likely to be found.

Scott Kafker 